\title{
Girdles as the main infection site for Paradeontacylix kampachi (Sanguinicolidae) in the greater amberjack Seriola dumerili
}

\author{
Francisco E. Montero*, F. Javier Aznar, Mercedes Fernández, Juan A. Raga \\ Departamento de Zoologia Animal and Instituto Cavanilles de Biodiversidad y Biología Evolutiva, Universitat de Valencia, PO Box 22085 , \\ Valencia 46071, Spain
}

\begin{abstract}
In this study, we provide new information about the habitats selected by the blood fluke Paradeontacylix kampachi in the greater amberjack Seriola dumerili based on an exhaustive anatomical examination. From May to October 1998, 21 fish of the 0+ age class were collected from tanks of the Spanish Institute of Oceanography in Puerto de Mazarrón, Spain, for parasitological analysis. Individuals of P. kampachi were found in 17 of the 21 fish analysed (mean intensity \pm SD: $13.6 \pm 16.6$; median: 6 ). Worms occurred in the girdles, cephalic kidney, sinus venosus, kidney and branchial arteries. A Friedman test with a post-hoc contrast revealed a significantly higher number of worms in the girdles when compared with the other sites, suggesting this may be the main habitat for P. kampachi. This location had never been reported as a habitat for any species of Paradeontacylix, probably because it had not been examined before. Girdles should be routinely examined to estimate the actual intensity of infection and to maximize the likelihood of finding this species of digenean.
\end{abstract}

KEY WORDS: Seriola dumerili - Aquaculture · Habitat . Sanguinicolidae $\cdot$ Paradeontacylix kampachi

Resale or republication not permitted
without written consent of the publisher

Blood flukes of the family Sanguinicolidae (Digenea) provoke important pathologies in cultured fish (Smith 1997). In particular, species of Paradeontacylix have been reported to cause mortalities in cultures of greater amberjack Seriola dumerili in the Spanish Mediterranean (Crespo et al. 1992, Grau 1994), and particularly in Japan (up to $80 \%$ of cultured fish) (Ogawa \& Fukudome 1994). An adequate control of the disease requires more knowledge of the biology of these parasites. Two species have been described in $S$. dumerili, namely $P$. grandispinus and P. kampachi (Ogawa \& Egusa 1986). The complete life cycle of these species is unknown; the only events thus far described are those occurring in the definitive host. Like in other sanguinicolids, eggs released by the adults are transported by the circulatory system and accumulate in the capillaries of the gill lamellae, where they hatch; the miracidia break the gill epithelium and reach the environment (Ogawa et al. 1989, Grau 1994). Information about habitat selection is also incomplete. Some authors (Crespo et al. 1992, Grau 1994, González et al. 1995) reported some habitats for Paradeontacylix sp., but did not provide detailed information about all the sites examined. Owaga et al. (1993) examined the afferent branchial arteries, ventral aorta, bulbus arteriosus, heart and sinus venosus of $S$. dumerili infected with $P$. grandispinus and P. kampachi. However, these authors did not examine the blood vessels in other parts of the fish body due to technical difficulties. In this study, we provide new information about the habitats selected by P. kampachi based on a comprehensive anatomical examination of a sample of $S$. dumerili.

Material and methods. Since 1993, juvenile Seriola dumerili have routinely been captured off Puerto de Mazarrón, Spain $\left(37^{\circ} 29^{\prime}\right.$ to $37^{\circ} 34^{\prime} \mathrm{N}, 1^{\circ} 9^{\prime}$ to $\left.1^{\circ} 15^{\prime} \mathrm{W}\right)$ and brought to the facilities of the Spanish Institute of Oceanography in this locality to be reared in experimental tanks. Specimens of Paradeontacylix have frequently been detected in these cultures (González et al. 1995, Montero et al. 1999, 2001). From May to October 1998, 21 fish of the 0+ age class were collected from the tanks for parasitological analysis. Fish were killed with an overdose of benzocaine. Prior to parasitological examination, ligatures were made with nylon string to block passage between ventral aorta and bulbus arteriosus, bulbus arteriosus and ventricle, ventricle and auricle, heart and sinus venosus plus Cuvier ducts, Cuvier ducts and thoracic plus pelvic veins, and Cuvier ducts and hepatic veins. Subsequently, the gills (including lamellar and branquial arteries), ventral aorta, bulbus arteriosus, ventricle, auricle, sinus venosus and Cuvier ducts, caudal vein, cephalic kidney, kidney, liver, spleen, stomach, intestine, intestinal ceca, pancreas, eyes and brain were 
Table 1. Paradeontacylix kampachi in different parts of body of 17 infected greater amberjacks Seriola dumerili from Puerto de Mazarrón, Spain

\begin{tabular}{|lccc|}
\hline Habitat & $\begin{array}{c}\text { Total number } \\
\text { of worms }\end{array}$ & $\begin{array}{l}\text { Mean number } \\
\text { of worms } \pm \text { SD }\end{array}$ & Median \\
\hline Girdles & 120 & $7.1 \pm 9.1$ & 3 \\
Cephalic kidney & 60 & $3.5 \pm 6.0$ & 1 \\
Sinus venosus & 33 & $1.9 \pm 2.7$ & 0 \\
Kidney & 12 & $0.7 \pm 1.2$ & 0 \\
Branchial arteries & 6 & $0.4 \pm 1.0$ & 0 \\
\hline
\end{tabular}

examined separately. For the analysis of skeletal musculature, the vertebral column was removed and the carcass was divided into 4 parts, i.e. head, pectoral and pelvic girdles, abdomen, and tail. Muscle was teased apart in Petri dishes with saline and examined under a stereomicroscope.

Results and discussion. A total of 231 individuals of Paradeontacylix kampachi were found in 17 of the 21 fish analysed $(81 \%$ at a mean intensity of $13.6 \pm 16.6$; median: 6). In the remaining fish, only eggs were detected. Worms occurred in the girdles (14 fish), cephalic kidney (9), sinus venosus (8), kidney (7) and branchial arteries (3). The number of worms in each site are shown in Table 1. A Friedman test revealed significant differences in the number of worms per site $\left(F_{4,64}=8.43, \mathrm{p}<0.0001\right)$. A post-hoc contrast (Conover 1999) indicated the following pattern of differences $(\mathrm{p}<0.05)$ : girdles differed from all other sites, and the sinus venosus and the cephalic kidney differed from the branchial arteries. These results suggest that the girdles might be the main habitat for P. kampachi. This location had never been reported as a habitat for any species of Paradeontacylix, probably because it had not been examined (Ogawa et al. 1993). This might be one of the reasons why eggs but not worms of Paradeontacylix spp. were frequently detected (Crespo et al. 1992, Ogawa et al. 1993, Ogawa \& Fukudome 1994, Montero et al. 1999). Therefore, the girdles should be routinely examined to estimate the actual intensity of infection and to maximize the likelihood of finding worms. Whether this habitat is also important for the other species of Paradeontacylix, P. grandispinus, occurring in Seriola dumerili is an interesting question that deserves immediate attention.

Editorial responsibility: Wolfgang Körting,

Hannover, Germany
Acknowledgements. We thank Antonio García and Fernando de la Gándara (Instituto Español de Oceanografía) for technical support. This study has been supported by project OCYT No. GV-01-9 from the Valencian Government and Ministry of Science and Technology of Spain (MCYT) No. BOS2002-878. F.J.A. benefits from a 'Ramón y Cajal' contract from the MCYT of Spain.

\section{LITERATURE CITED}

Conover WJ (1999) Practical nonparametric statistics, 3rd edn. John Wiley \& Sons, New York

Crespo S, Grau A, Padrós F (1992) Sanguinicoliasis in the cultured amberjack Seriola dumerili Risso, from the Spanish Mediterranean area. Bull Eur Assoc Fish Pathol 12: $157-159$

González G, García A, Jover M, Crespo S (1995) Influence of artificial food on 1+ amberjack (Seriola dumerili, Risso) sanguinicoliasis and epitheliocystis. Bull Eur Assoc Fish Pathol 15:14-16

Grau A (1994) Aspectos histológicos, ciclo reproductor y principales procesos patológicos de Seriola dumerili, Risso 1810 (Carangidae). PhD thesis, Universitat Autònoma de Barcelona

Kirk RS, Lewis JW (1996) Migration and development of the blood fluke Sanguinicola inermis Plehn, 1905 (Trematoda: Sanguinicolidae) in carp Cyprinus carpio L. Parasitology 113:279-285

Montero FE, García A, Raga JA (1999) First record of Paradeontacylix sp McIntosh, 1934 (Digenea: Sanguinicolidae) in Mediterranean amberjack (Seriola dumerili (Risso, 1810)) culture. Bull Eur Assoc Fish Pathol 19(3):107

Montero FE, García A, De la Gándara F, Raga JA (2001) Parásitos del cultivo de la lecha (Seriola dumerili) en el Mediterráneo occidental. Monogr Inst Canario Cienc Mar 4:513-518

Ogawa K, Egusa E (1986) Two new species of Paradeontacylix McIntosh, 1934 (Trematoda: Sanguinicolidae) from the vascular system of a cultured marine fish Seriola purpurascens. Fish Pathol 21:15-19

Ogawa K, Fukudome M (1994) Mass mortality caused by blood fluke (Paradeontacylix) among amberjack (Seriola dumerili) imported to Japan. Fish Pathol 29(4):265-269

Ogawa K, Hattori K, Hatai K, Kubota S (1989) Histopathology of cultured marine fish, Seriola purpurascens (Carangidae) infected with Paradeontacylix spp. (Trematoda: Sanguinicolidae) in its vascular system. Fish Pathol 24(2): $75-81$

Ogawa K, Andoh H, Yamaguchi M (1993) Some biological aspects of Paradeontacylix (Trematoda: Sanguinicolidae) infection in cultured marine fish Seriola dumerili. Fish Pathol 28(4):177-180

Smith JW (1997) The blood flukes (Digenea: Sanguinicolidae and Spirorchidae) of cold-blooded vertebrates: Part 1. A review of the literature published since 1971, and bibliography. Helminthol Abs 66:255-294

Submitted: February 13, 2002; Accepted: October 10, 2002

Proofs received from author(s): January 30, 2003 